FACED with two proposals for dealing with their company's liquidity crisis, employees of George Kent Ltd have voted in favour of an arrangement with the Swiss company Brown Boveri which would give Kent more cash to the tune of $£ 6$ million but leave effective control of the company in the United Kingdom. The name Kent on scientific instruments is well known in its own right in research laboratories, as is that of a company which it owns-Cambridge Scientific Instruments.

The result of this exercise in industrial democracy flew in the face of $\mathrm{Mr}$ Anthony Benn, Secretary of State for Industry, who preferred an arrangement whereby George Kent would be taken over by GEC, Sir Arnold Weinstock's company. But Mr Benn was also keen that Kent's employees should have a chance to make their views known and now has to decide, in the light of by the mooted Brown Boveri Kent Ltd, the ballot, how to use the $24 \%$ of the and this is where some Kent employees Kent shares which the government part company with the Brown Boveri win the day.

\section{Business report}

\section{by Roger Woodham}

shares but it has now decided to be content with less than $50 \%$, thus assuaging fears that control of George Kent would be lost to a foreign company. It also envisages Kent's scientific and medical instruments business being owns when it comes to a vote among plans. The 600 employees of Camshareholders. If he decides to go along bridge Scientific Instruments voted in with the Brown Boveri plan it seems favour of the GEC plan to a man bealmost certain to be the one that will cause they regard an independent that it should buy $53 \%$ of the of the 7,300 employees said yes to Brown Boveri. set up as a separate company owned
This desire to run into the arms of of a Swiss-based multinational is almost certainly based on fears that 'rationalisation' after a takeover by GEC would threaten job security. By contrast there is little overlap between the activities of Kent and Brown Boveri, and the latter sees Kent as a useful marketing base in the United Kingdom. Indeed the prospect of access to France, Germany and Switzerland, where Brown Boveri sells some $£ 780$ million worth of equipment and where neither Kent nor GEC is particularly strong, is an added attraction from Kent's point of view. major differences in both methods and aims. With his background in enzyme evolution and bacterial adaptation, Hartley expects to rely very much more heavily than the Murrays on the adaptive potential of the bacteria themselves. This might be used, for example, to produce enzymes stable enough to survive long periods of storage at room temperature. The first step would be to introduce the gene into Bacillus stearothermophilus, which thrives at high temperatures. If an environment could then be devised in which the bacterium's survival would be greatly enhanced by the production of large quantities of the new enzyme, the bacterium would be under considerable selective pressure not only to make the enzyme, but to evolve a structure for it that would be stable at high temperatures.

In a collaborative effort with the Microbial Research Establishment at Porton, Hartley has already achieved the purification to homogeneity of 20 enzymes from thermophilic bacteria, in quantities of $50 \mathrm{~kg}$. The facilities are to be moved to Imperial College in January 1975, and the intention is eventually to produce enzymes for sale to industry. There is also the possibility of selling enzymes for research to other laboratories. Imperial College has at its disposal a potential wealth of restriction enzymes in the vast range of organisms grown there for antibiotic research. Isolation and purification of these enzymes will be an important part of the research programme.

The problem of maximising bacterial production of a particular enzyme for either commercial or research purposes may be another case in which the answer lies in the versatility of the bacteria themselves. In the case of phage lambda, there is a well known promotor system which it may be possible to commandeer. This enzyme system, together with the product of another phage gene, can override the controls which normally serve to prevent or limit the transcription of a given gene. Up to half the cell's synthetic capacity may in consequence be recruited to the production of a single type of protein molecule. In bacteria, however, it may actually be possible to increase the number of genes from which transcription of a given mRNA taken place. Hartley and his colleagues have recently demonstrated (Nature, 251, 200; 1974) that bacteria often respond to metabolic demands for large quantities of a particular enzyme by duplication of the genes which code for i.t. Again, of course, this technique would involve manipulation of the environment and not the bacterium.

Hartley draws a categorical distinction between the prospect of getting bacteria to mass-produce enzymes to human specifications (science), and that of inducing them to make mammalian hormones such as insulin (science fiction). This is partly because of his own emphasis on bacterial evolutionary potential in the implementation of human designs. While it may not be too difficult to devise environmental exigencies that would force a bacterium into an unnatural need for an outré enzyme, it is extremely difficult to imagine how one might provide it with an incentive to produce insulinalthough with elaborate genetic manipulation it may be possible. Hartley is not, however, among those who think trans- lation will be a major problem, though he concedes it is the rate-limiting step. But in view of the extensive use already made in industry of microbial enzymes, not to mention long-term plans for solving the global food problem with microbial proteins, bacterial enzyme production may prove quite enough to be getting on with.

\section{Little Red greenery book}

from our Soviet Correspondent

THE all-Union Botanical Society of the USSR has completed compilation of its "Red Book" of flora, listing some 20,000 forms in need of governmental protection, some 600 of which are in immediate danger of extinction.

In commenting on the report, Pravda predictably pays prime attention to those species which provide "irreplaceable" raw material, such as the Siberian and Korean cedars, and the Caucasian ironwood, and notes that such valuable species as the waterfall poplar, Vavilov's almond, and the Kolyma currant are apparently, already, irretrievably lost.

Nevertheless, the red book also includes plants which have so far found no economic use, including certain weeds "against which mankind has waged an agelong struggle". This would appear, at first glance, contrary to Soviet utilitarian theories, but, the commentator explains, the "dialectics of 'harm' and 'use' is in this case complicated and contradictory", and quotes the classic case of penicillin in order to justify the presence of the weeds. 